\title{
Toxins from the Caribbean sea anemone Bunodeopsis globulifera increase cisplatin-induced cytotoxicity of lung adenocarcinoma cells
}

Heidi I Monroy-Estrada ${ }^{1,2,3}$, Yolanda I Chirino ${ }^{2}$, Irma E Soria-Mercado ${ }^{1}$ and Judith Sánchez-Rodríguez ${ }^{3^{*}}$

\begin{abstract}
Background: Lung cancer causes 1.4 million deaths worldwide while non-small-cell lung cancer (NSCLC) represents $80-85 \%$ of the cases. Cisplatin is a standard chemotherapy against this type of cancer; however, tumor cell resistance to this drug limits its efficacy. Sea anemones produce compounds with pharmacological activities that may be useful for augmenting cisplatin efficacy. This study aimed to evaluate the pharmacological activities of crude venom (CV) from the sea anemone Bunodeopsis globulifera and four derived fractions (F1, F2, F3 and F4) to test their increase efficiency cisplatin cytotoxicity in human lung adenocarcinoma cells.

Results: Pre-exposure to CV, F1 and F2 fractions increases cisplatin cytotoxicity in human lung adenocarcinoma cells under specific conditions. Exposure to CV at $50 \mathrm{\mu gmL}^{-1}$ induced a reduction of approximately $50 \%$ in cell viability, while a similar cytotoxic effect was observed when cell culture was exposed to F1 at $25 \mathrm{\mu gmL}^{-1}$ or F2 at $50 \mathrm{\mu gmL}^{-1}$. The cell culture exposure to $\mathrm{F} 1\left(10 \mathrm{\mu gmL}^{-1}\right)$ fraction combined with cisplatine $(25 \mu \mathrm{M})$ provoked a decrease in MTT reduction until $65.57 \%$ while F2 $\left(25 \mu \mathrm{gmL}^{-1}\right)$ fraction combined with cisplatin (10 $\left.\mu \mathrm{M}\right)$ provoked a decrease in MTT reduction of $72.55 \%$.

Conclusions: The F1 fraction had the greatest effect on the lung adenocarcinoma cell line compared with CV and F2. The combination of antineoplastic drugs and sea anemone toxins might allow a reduction of chemotherapeutic doses and thus mitigate side effects.
\end{abstract}

Keywords: Cnidaria, Pharmacology, Human lung cancer cells, Cytotoxicity assay, Cisplatin efficacy

\section{Background}

According to the International Agency for Research on Cancer (IARC) and World Health Organization, cancer is a leading cause of death worldwide, accounting for 7.6 million deaths (around 13\% of all deaths) in 2008. Lung cancer causes 1.4 million deaths, followed by stomach $(740,000$ deaths), liver $(700,000$ deaths), colorectal (610,000 deaths) and breast cancer (460,000 deaths). Around $70 \%$ of all cancer deaths occurred in low- and middle-income countries. Projections to 2030, indicate about 11 million of cancer deaths worldwide and it is

\footnotetext{
*Correspondence: judithsa@cmarl.unam.mx

${ }^{3}$ Unidad Académica de Sistemas Arrecifales, Puerto Morelos, Instituto de Ciencias del Mar y Limnología, Universidad Nacional Autónoma de México, Puerto Morelos, Quintana Roo State, Mexico

Full list of author information is available at the end of the article
}

expected that non-small-cell lung cancer (NSCLC) will represent $80-85 \%$ of cases.

NSCLC, which comprises adenocarcinoma, squamous cell carcinoma and large-cell carcinoma, is an exclusion diagnosis [1]. Platinum-based chemotherapeutics are the most common regimens for NSCLC patients but resistance and side effects have limited their efficiency [2-4]. In this regard, Cis-diammine-dicholoplatinium (II), known as cisplatin, is an antineoplastic drug widely used in the treatment of many solid tumors, including lung, head, neck, ovary, breast, colorectal and cervical cancers $[5,6]$. However, the usage of cisplatin in cancer treatment is limited due to resistance and side effects including nephrotoxicity [7].

\section{Biomed Central}

(c) 2013 Monroy-Estrada et al.; licensee BioMed Central Ltd. This is an Open Access article distributed under the terms of the Creative Commons Attribution License (http://creativecommons.org/licenses/by/2.0), which permits unrestricted use, distribution, and reproduction in any medium, provided the original work is properly cited. 
The abovementioned problem has led to the development of new strategies to achieve effectiveness against cancer. In this sense, the peptides and proteins found in marine venoms may increase the efficacy of conventional chemotherapeutic drugs [8]. In particular, sea anemones produce peptides and proteins that act as cytolysins which are classified based on their molecular weight as follows: $5-8 \mathrm{kDa}$ peptides with antihistamine activity; $\sim 20 \mathrm{kDa}$ pore-forming proteins; $\sim 30-40 \mathrm{kDa}$ cytolysins with or without phospholipase $\mathrm{A}_{2}$ activity; and a putative protein group $\sim 80 \mathrm{kDa}[9]$.

An essential feature of cytolysins is their ability to form pores in biological membranes, which lead to osmotic changes and loss of intracellular metabolites thereby provoking cell death $[10,11]$. However, cytolysins may induce cell damage in both normal and cancer cells if attached to their membrane. Nevertheless, characteristics of cancer cells are different from normal cells, including gene profile expression, metabolism and membrane features. In this regard, it has been demonstrated that cytolysins can induce more damage in cancer cells due to their differences from normal cells. For this reason, cytolysins have been proposed as an alternative for cancer therapy $[8,12,13]$.

For example, actinoporins isolated from the tropical sea anemone Heteractis crispa have shown anticancer properties through the induction of p53-independent apoptosis [14]. Bunodeopsis globulifera - found in the reef lagoon at Puerto Morelos, Quintana Roo, Mexico has been reported as producing a highly dangerous sting, probably due to the toxins it contains [15]. However, the potential benefits of $B$. globulifera have been not been documented. In the present work we hypothesized that toxins from B. globulifera could increase cytotoxicity induced by an antineoplastic agent against cancer cells. Specifically, we are interested in lung cancer cells because the incidence and mortality rates are among the highest in the world. This study aimed to investigate the ability of crude venom $(\mathrm{CV})$ and fractions extracted from the sea anemone B. globulifera to increase the cisplatin-induced cytotoxicity in lung adenocarcinoma cells. Our results showed for first time the ability of Bunodeopsis globulifera CV and fractions to increase the cytotoxic effect of a common antineoplastic agent used in several types of cancer.

At this point it should be mentioned that toxins from Bunodeopsis globulifera are cytotoxic like other cnidarian venoms. However, the purpose of this work is to test whether the usage of low concentrations of toxins can increase the effect of a low concentration of a common antineoplasic agent. The general objective of this research is to design a strategy to decrease the concentrations of cisplatin and toxins, since this could be helpful in avoiding the side effects of higher concentrations. For example, cisplatin is useful to treat lung cancer but provokes nephrotoxicity as its main side effect. The combination of two drugs may facilitate the diminution of the side effects associated with higher doses.

\section{Methods \\ Reagents}

F-12K Nutrient Mixture medium was purchased from Gibco Invitrogen (USA). RPMI-1640 medium was obtained from In Vitro, S.A (Mexico). Fetal bovine serum (FBS) was from PAA Laboratories (Canada). Cisplatin (cat. n. P4394) and 3-(4,5-dimethylthiazol-2-yl)- 2,5-diphenyltetrazolium bromide (MTT; cat. n. M2128) were purchased from Sigma Chemical Co. (USA). Lactate dehydrogenase kit (cat. n. 630117) was obtained from Clontech Laboratories, Inc (USA). Quick Start Bradford Protein Assay Kit (cat. n. 5000202) was bought from Bio-Rad Laboratories, Inc (USA). Sephadex G-50 Medium Gel (cat. n. 17-0043-02) was obtained from Pharmacia Biotech (Sweden).

\section{Cell cultures}

Human A549 non-small-cell lung cancer line, which is an adenocarcinoma epithelial-derived cell line, was obtained from the American Type Culture Collection (ATCC, USA).

Cells were cultured in monolayers at $37^{\circ} \mathrm{C}$ in a humidified atmosphere of $5 \% \mathrm{CO}_{2}$ in $\mathrm{F} 12 \mathrm{~K}$ medium supplemented with $10 \%$ heat-inactivated FBS.

\section{Isolation and Pre-purification of crude venom}

Specimens of Bunodepsis globulifera were collected from the reef lagoon at Puerto Morelos, Quintana Roo, Mexico, by scuba diving between February and June, 2009 and from May to June, 2011. The sea anemones were identified by Ricardo Gonzalez-Muñoz. The crude venom was obtained by mincing and homogenizing the whole body of the sea anemone, and then centrifuging at $3200 \mathrm{~g}$ for 15 minutes at $4^{\circ} \mathrm{C}$, after which the supernatant was lyophilized. The crude lyophilized venom ( $4 \mathrm{~g}$ ) was purified by Sephadex G-50 M gel filtration column $(85 \times 5 \mathrm{~cm})$ equilibrated with $0.3 \mathrm{M}$ acetic acid buffer and eluted with the same buffer at a flow rate of $2 \mathrm{~mL} \mathrm{~min}^{-1}$. The four fractions obtained were concentrated and lyophilized.

\section{Cytotoxicity assays}

Lung adenocarcinoma cells $\left(1 \times 10^{4}\right.$ per well/150 $\left.\mu \mathrm{L}\right)$ were incubated in 96-well plates and cultured for 24 hours to allow adherence. After this time, cell culture was exposed to the following treatments: $1,10,25,50,75,100$ and $200 \mu \mathrm{gmL}^{-1}$; and 10 and $25 \mu \mathrm{gmL}^{-1}$ of $\mathrm{CV}, \mathrm{BgG} 50 \mathrm{~F} 1$ and BgG50F2 fractions of B. globulifera for 24 hours, $37^{\circ} \mathrm{C}$ and $5 \%$ of $\mathrm{CO}_{2}$ atmosphere. After each treatment, the cells were exposed to cisplatin $10 \mu \mathrm{M}$ or cisplatin $25 \mu \mathrm{M}$ for 24 hours.

\section{Cell viability assay and cytotoxicity}

Cell viability was measured by the reduction of MTT to formazan blue. Cell culture was incubated with $0.5 \mathrm{mg} / \mathrm{mL}$ 


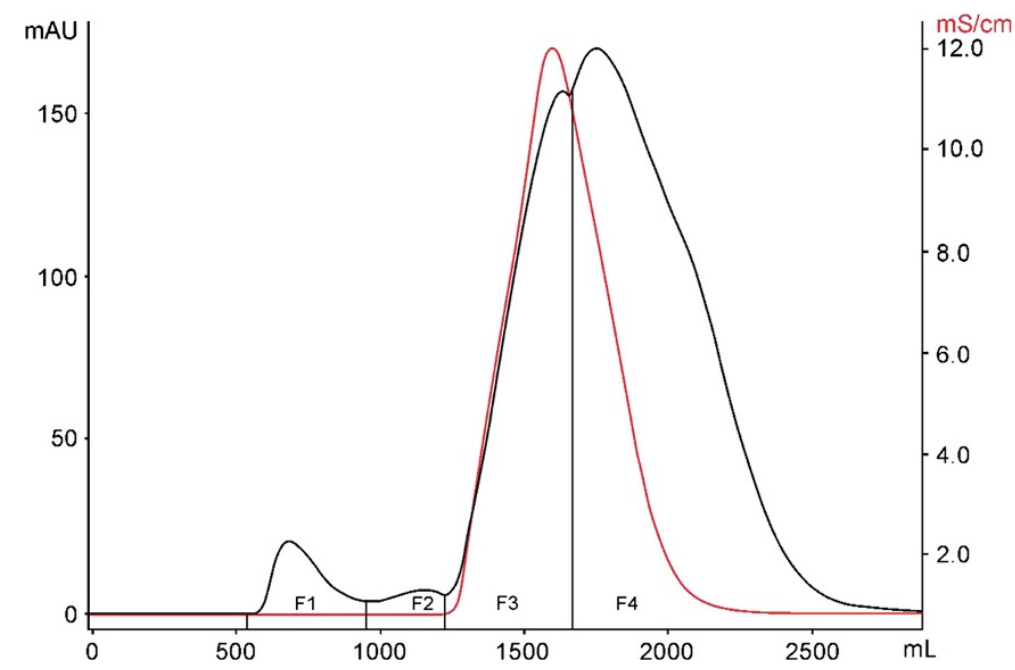

Figure 1 Gel filtration chromatography Sephadex G-50 M of CV (4 g) from B. globulifera. The column was equilibrated and eluted with $0.3 \mathrm{M}$ acetic acid buffer at a flow rate of $2 \mathrm{~mL} \mathrm{~min}^{-1}$ to obtain the fractions F1, F2, F3 and F4.

MTT at $37^{\circ} \mathrm{C}$ in an atmosphere of $5 \% \mathrm{CO}_{2}$ for 2 hours. The medium was removed and the formazan blue crystals were dissolved in isopropyl alcohol for measuring the optical density at $540 \mathrm{~nm}[16]$.

The cytotoxicity was measured using a lactate dehydrogenase (LDH) cytotoxicity detection kit according to the manufacturer's protocol. Briefly, supernatants from cell treatments were collected and diluted 1:3 with PBS. After that, supernatant dilution was mixed 1:1 with dye solution and incubated at $37^{\circ} \mathrm{C}$ for 30 minutes under agitation; and absorbance was measured at $540 \mathrm{~nm}$.

\section{Quantification of protein}

The protein content was measured by the Bradford assay [17] using bovine gamma globulin (BGG) as standard.

\section{SDS-PAGE electrophoresis}

The obtained fractions were assessed by SDS-PAGE according to Laemmli [18] using a $12 \%$ polyacrylamide gel for the molecular weight determination.

\section{Statistical analysis}

Data were expressed by mean $\pm \mathrm{SD}$, followed by one-way analysis of variance (ANOVA) with Bonferroni's multiple comparison tests, performed using GraphPad Prism for Windows (GraphPad Software, USA). $p<0.001$ was considered to be statistically significant.

\section{Results}

\section{Pre-purification of crude venom from $B$. Globulifera}

Crude venom $(\mathrm{CV})$ of $B$. globulifera was obtained by mincing and homogenizing the whole body of the sea anemone. It was centrifuged at $3200 \mathrm{~g}$ for 15 minutes at $4^{\circ} \mathrm{C}$, and the supernatant was lyophilized. Crude venom was purified by gel filtration in a Sephadex G-50 M column and eluted with $0.3 \mathrm{M}$ acetic acid buffer at a flow rate of $2 \mathrm{~mL} \mathrm{~min}^{-1}$. Four fractions - F1, F2, F3 and F4 - were obtained. Thereafter, fractions were vacuum-concentrated and lyophilized (Figure 1). Table 1 shows the protein content of CV, F1, F2, F3 and F4 quantified by the Bradford method [17].

The cytotoxic effects of CV as well as the F1, F2, F3 and F4 fractions were tested on a human lung adenocarcinoma cell line using an MTT assay. The exposure to $1 \mu \mathrm{gmL}^{-1}$ or $10 \mathrm{\mu gmL}^{-1}$ to $\mathrm{CV}$ did not induce changes in MTT reduction. However, $\mathrm{CV}$ at $25 \mathrm{\mu gmL}^{-1}, 50 \mu \mathrm{gmL}^{-1}, 75 \mu \mathrm{gmL}^{-1}$, $100 \mathrm{ggmL}^{-1}$ and $200 \mu \mathrm{gmL}^{-1}$ decreased cell viability by the following percentages: 33.37, 55.46, 65.8, 68.36 and 70.44, respectively (Figure 2A). The exposure to F1 at $1 \mu^{-1} \mathrm{gm}^{-1}$ or $10 \mu \mathrm{gmL}^{-1}$ did not show a cytotoxic effect; however, $25 \mu \mathrm{gmL}^{-1}, 50 \mu \mathrm{gmL}^{-1}, 75 \mu \mathrm{gmL}^{-1}, 100 \mu \mathrm{gmL}^{-1}$ and $200 \mathrm{\mu gmL}^{-1}$ induced respective decreases in cell viability of 47.11\%, 60.21\%, 65.27\%, 70.87\% and 72.35\% (Figure 2B). The exposure to F2 at $1 \mu \mathrm{gmL}^{-1}$ or $10 \mathrm{\mu gmL}^{-1}$ did not produce any change in MTT reduction, but $50 \mathrm{\mu gmL}^{-1}$, $75 \mu \mathrm{gmL}^{-1}, 100 \mathrm{\mu gmL}^{-1}$ and $200 \mathrm{\mu gmL}^{-1}$ induced cellviability diminutions of $36.49 \%, 55.83 \%, 69 \%, 71.27 \%$ and $77.13 \%$, respectively (Figure $2 \mathrm{C}$ ). The F3 and F4 did not

Table 1 Protein quantification of CV and fractions isolated from B. globulifera at $1 \mathrm{mgmL}^{-1}$ using the Bradford method

\begin{tabular}{cc}
\hline Sea anemone toxins & Protein $(\boldsymbol{\mu g})$ \\
\hline Crude venom & 32.4 \\
Fraction F1 & 157.7 \\
Fraction F2 & 152.6 \\
Fraction F3 & 20.4 \\
Fraction F4 & 19.7 \\
\hline
\end{tabular}



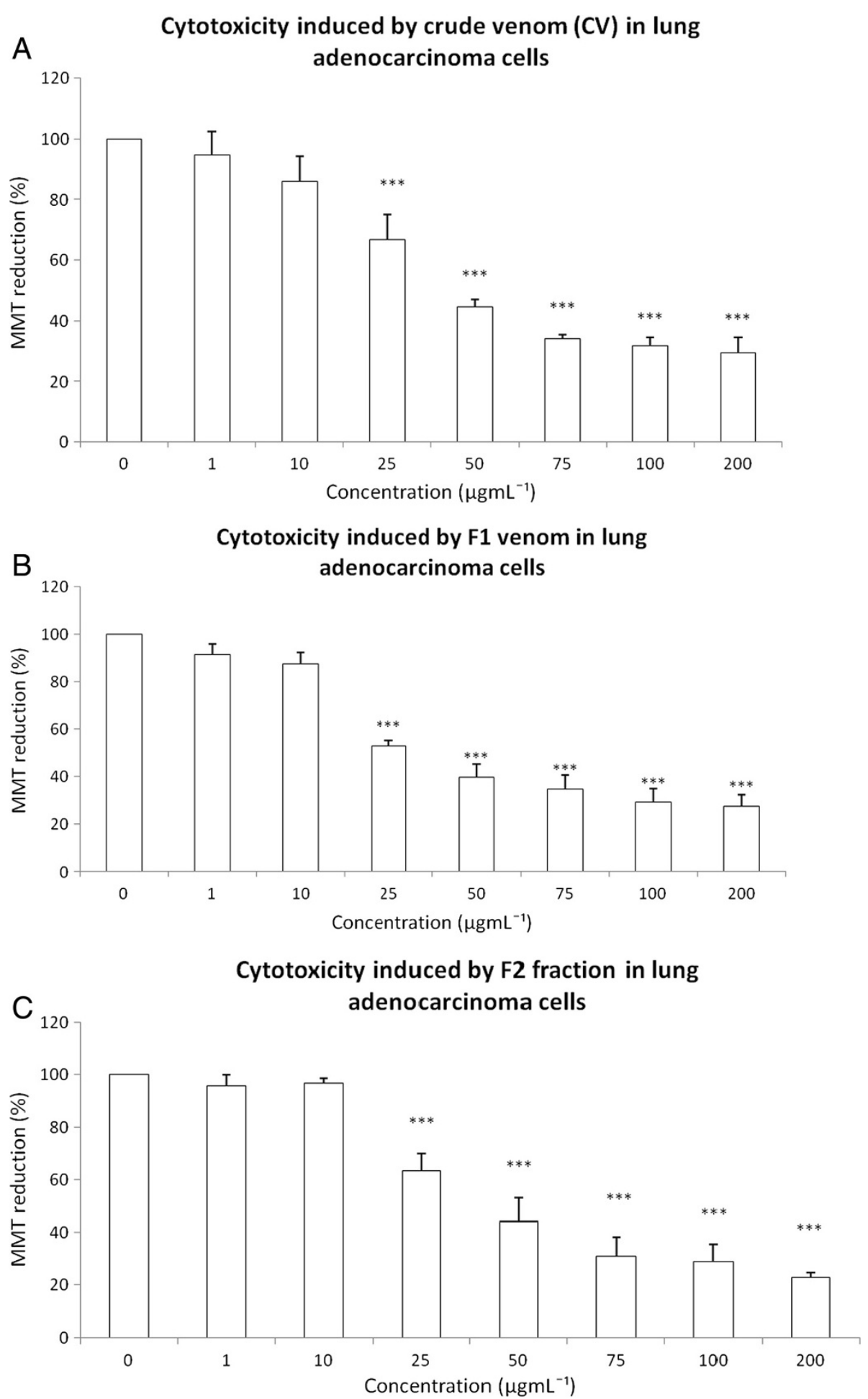

Figure 2 Cytotoxicity induced by CV and the fractions F1 and F2 from B. globulifera at the concentrations 1, 10, 25, 50, 75, 100 and $200 \mu \mathrm{gmL}^{-1}$ on lung adenocarcinoma cell culture. Effect of: (A) CV, (B) F1 fraction, (C) F2 fraction. Graphs show the percentage of MTT reduction. Data are expressed as the mean \pm SD of four independent experiments. Significance was defined as *** $p<0.001$ (ANOVA, Bonferroni's post test) in comparison with the untreated control values (100\%). 


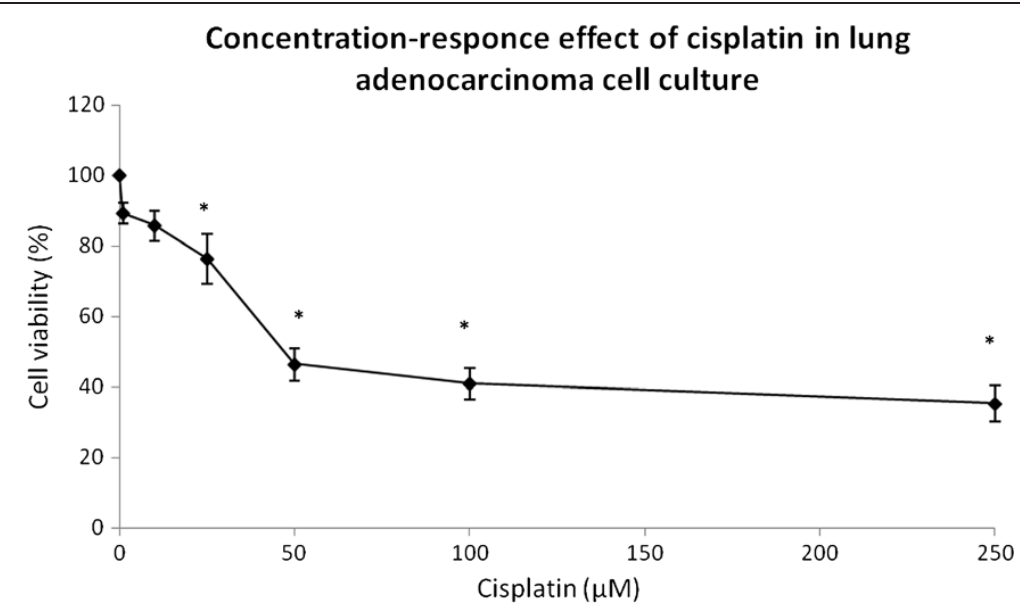

Figure 3 Concentration-response effect of cisplatin on lung adenocarcinoma cell culture: cell viability was measured by MTT assay. Data are expressed as the mean \pm SD of four independent experiments. ${ }^{*} p<0.01$ vs. control, one-way analysis of variance, with Bonferroni's test.

alter MTT reduction (data not shown) and thus were not considered for further experiments in the present work.

\section{Inhibitory concentration (IC50) values for cisplatin}

The cisplatin concentration that inhibited cell growth by $50 \%$ (IC50) was determined in a human lung adenocarcinoma cell line. A cisplatin concentration between 1 and $250 \mu \mathrm{M}$ was used in cell culture for 24 hours in three independent experiments. After treatment, cytotoxicity was tested by MTT reduction and the IC50 found to be $50 \mu \mathrm{M}$ (Figure 3). However, concentrations below IC50 were used to test whether $\mathrm{CV}$ and its fractions could enhance the cisplatin cytotoxicity. Human lung adenocarcinoma cells exposed to cisplatin at 1 and $10 \mu \mathrm{M}$ remained without changes in MTT reduction; however, cisplatin concentrations of 25, 50, 100 and $250 \mu \mathrm{M}$ induced respective cellviability decreases of $23.64 \%, 53.59 \%, 58.98 \%$ and $64.64 \%$ (Figure 3). We selected cisplatin concentrations of $10 \mu \mathrm{M}$ and $25 \mu \mathrm{M}$, which are below the IC50.

\section{CV, F1 and F2 enhanced cisplatin-induced cytotoxicity}

Lung adenocarcinoma cells were pre-exposed to CV, F1 or $\mathrm{F} 2$ at $10 \mu \mathrm{gmL}^{-1}$ or $25 \mu \mathrm{gmL}^{-1}$ for 24 hours. After this time, the medium was removed and cell culture was washed and exposed to cisplatin at $10 \mu \mathrm{M}$ or $25 \mu \mathrm{M}$. The abovementioned strategy was executed in order to increase cisplatin cytotoxicity by pretreatment with $\mathrm{CV}$, F1 or F2 at low concentration.

The pretreatment with $\mathrm{CV}$ at $10 \mu \mathrm{gmL}^{-1}$ plus cisplatin at $25 \mu \mathrm{M}$ yielded a $26.47 \%$ decrease in cell viability; the pretreatment with $25 \mu \mathrm{gmL}^{-1} \mathrm{CV}$ plus $10 \mu \mathrm{M}$ cisplatin augmented the cell-viability decrease to $30.22 \%$. But the maximum effect was produced by $25 \mathrm{\mu gmL}^{-1} \mathrm{CV}$ plus $25 \mu \mathrm{M}$ cisplatin (Figure 4A). However, the pre-exposure to $\mathrm{CV}$ did not increase the cisplatin-induced cytotoxicity (Figure 4A).
The pre-exposure to $\mathrm{F} 1$ at $10 \mu \mathrm{gmL}^{-1}$ caused a decrease in MTT reduction induced by $10 \mu \mathrm{M}$ and $25 \mu \mathrm{M}$ of cisplatin to $66.39 \%$ and $68.4 \%$, respectively (Figure 4B). The pre-exposure to $25 \mu \mathrm{gmL}^{-1} \mathrm{~F} 1$ had similar effect; it reduced cell viability down to $72.55 \%$ after exposure to $25 \mu \mathrm{M}$ cisplatin (Figure 4B). The $10 \mu \mathrm{gmL}^{-1} \mathrm{~F} 2$ increased the cytotoxicity induced by $10 \mu \mathrm{M}$ cisplatin to $51.56 \%$ (Figure $4 \mathrm{C}$ ).

Then, while evaluating the LDH release into the cell culture medium as a loss of membrane integrity, we observed that $10 \mu \mathrm{gmL}^{-1} \mathrm{CV}$ plus $25 \mu \mathrm{M}$ cisplatin and $25 \mu \mathrm{gmL}^{-1}$ $\mathrm{CV}$ plus $25 \mu \mathrm{M}$ cisplatin induced significant increases of 2.665- and 2.799-fold in LDH release, respectively (Figure 5A). The pre-exposure to $\mathrm{F} 1$ at $25 \mu \mathrm{gmL}^{-1}$ plus cisplatin at $25 \mu \mathrm{M}$ produced a significant 2.858 fold increase in LDH release (Figure 5B). Pre-exposure to 10 and $25 \mathrm{\mu gmL}^{-1} \mathrm{~F} 2$ showed no statistical increase in cytotoxicity induced by 25 and $10 \mu \mathrm{M}$ cisplatin (Figure 5C).

\section{Discussion}

The present work showed that CV of B. globulifera and F1 and F2 obtained from pre-purification by Sephadex G-50 $M$ gel filtration chromatography induced cytotoxicity in a human lung adenocarcinoma cell line. Exposure to $\mathrm{CV}$ at $50 \mathrm{\mu gmL}^{-1}$ induced a reduction of approximately $50 \%$ in cell viability, while a similar cytotoxic effect was observed when cell culture was exposed to $\mathrm{F} 1$ at $25 \mu \mathrm{gmL}^{-1}$ or F2 at $50 \mu \mathrm{gmL}^{-1}$.

This cytotoxic effect has been also presented by other sea anemones, such as crude venoms of Heteractis magnifica, Stichodactyla haddoni and Parachondylactis sinensis on mouse fibroblast cell line L929 and leukemia cell line P388. In those studies, the decrease in cell viability was concentration-dependent [19]. EqTX-II cytolysin toxin from the sea anemone Actinia equina also induces a decrease in the viability of V-79-379 A cells (diploid lung fibroblast from Chinese Hamster) in a 

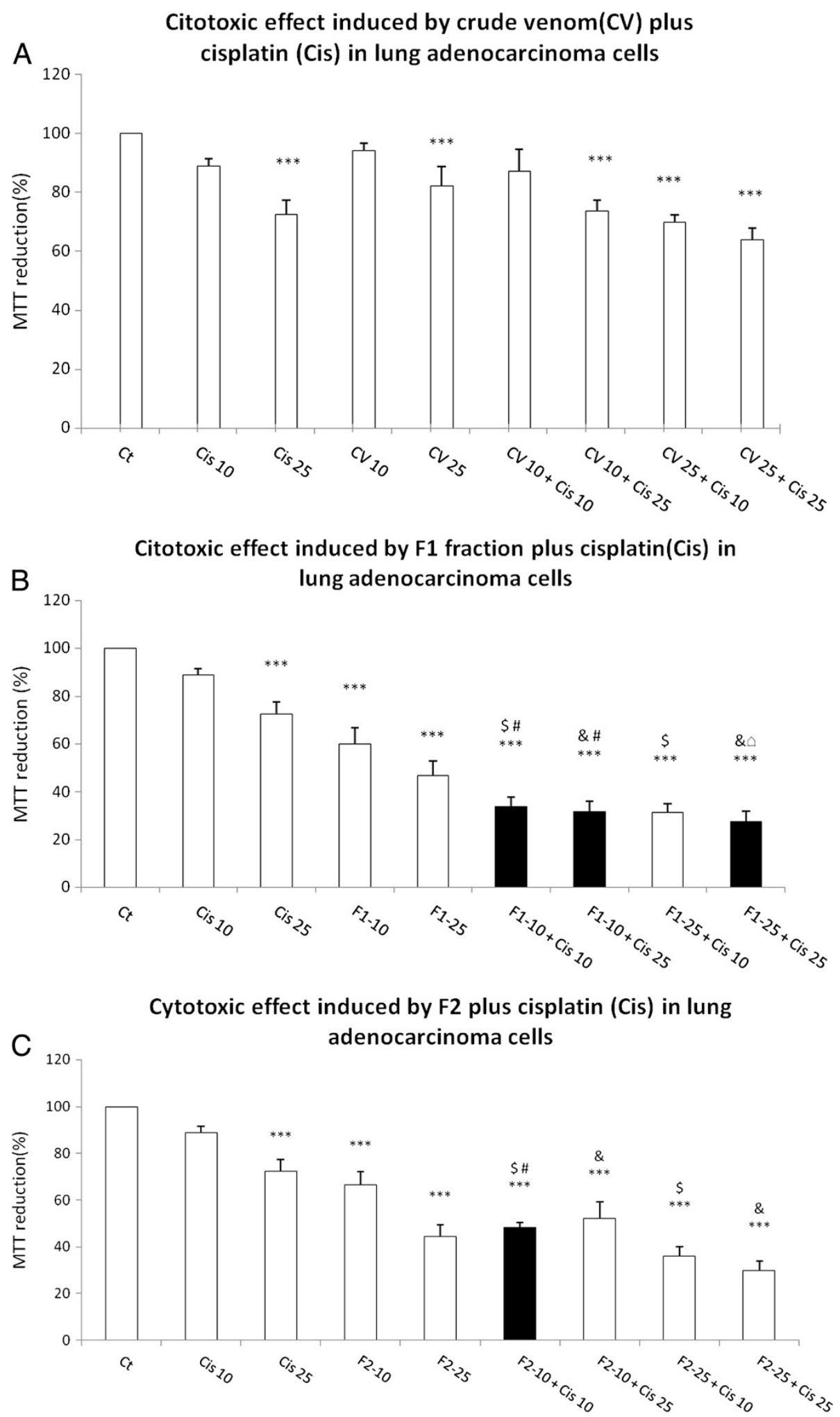

Figure 4 Cytotoxic effect induced by CV, F1 and F2 fraction from B. globulifera on adenocarcinoma lung cell culture. (A) CV, (B) F1 fraction plus cisplatin, (C) F2 fraction plus cisplatin. Graphs show the percentage of MTT reduction and data are expressed as the mean \pm SD of four independent experiments. ${ }^{* * *} p<0.001$ vs. control, ${ }^{\$} p<0.001$ vs. Cis $10,{ }^{\circledR} p<0.001$ vs. Cis $25,{ }^{*} p<0.001$ vs. CV 10 or F1-10 or F2-10, ${ }^{\square} p<0.001$ vs. CV 25 or F1-25 or F2-25 (One-way analysis of variance plus Bonferroni's test). Gray bars show the ability of (B) F1 and (C) F2 to augment the cisplatin decrease in MTT reduction. 


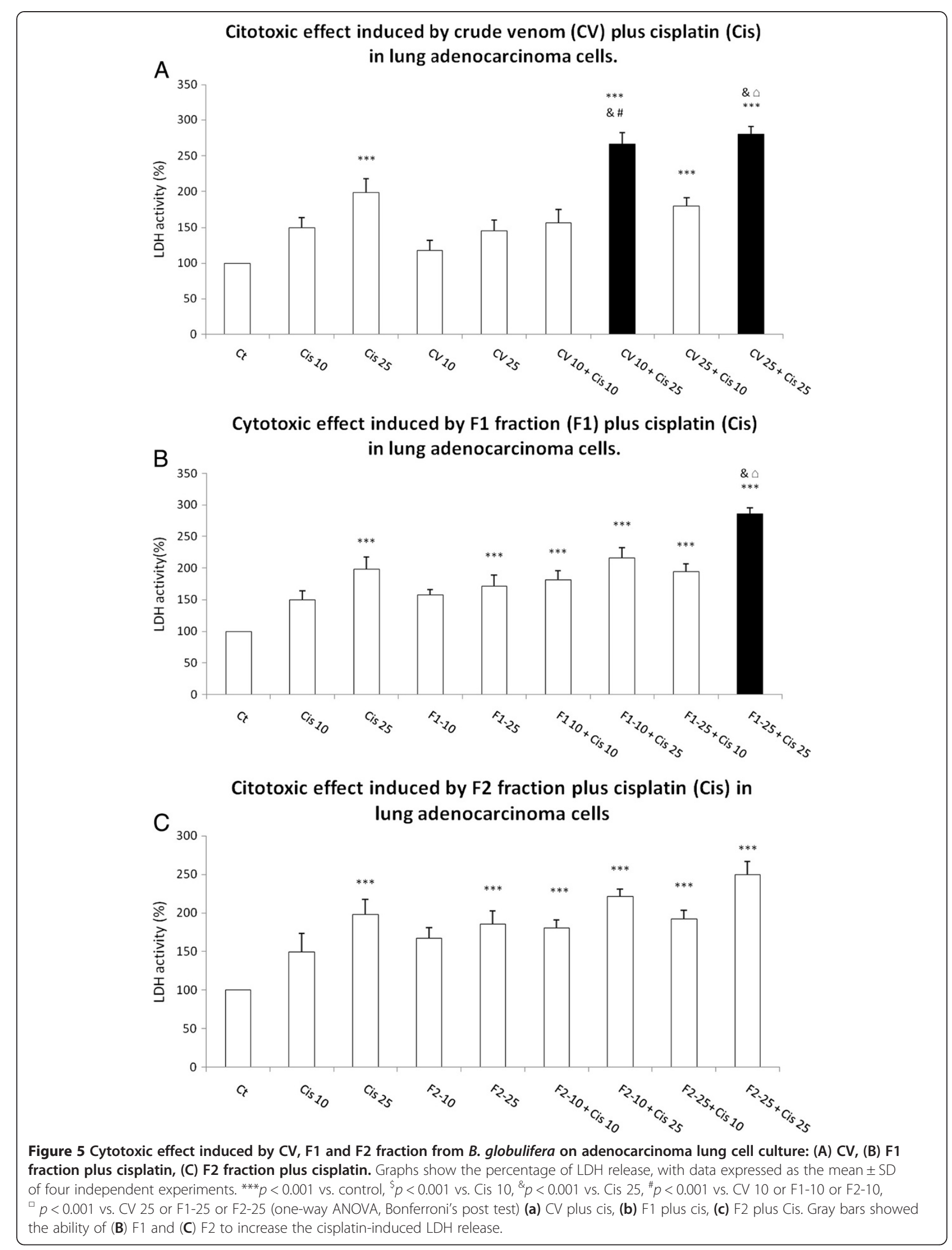


concentration-dependent manner [20]. RTX-A cytolysin from the sea anemone Heteractis crispa reduced cell viability of JB6 P $^{+}$Cl41 cells, Hela, THP-1, MDA-MB-231 and snu-c4 human tumor cell lines [14].

These results have shown that sea anemone toxins and some proteins derived from them exert cytotoxic activity on a non-small lung cancer cell lines, although the cytotoxic mechanisms induced by the sea anemone toxins have been sparsely investigated. In this regard, Soletti et al. [8] showed that the cytolysins EqTx-II and Bc2 from sea anemones potentiated the cytotoxicity induced by low-dose concentrations of the chemotherapeutic drugs against human glioblastoma cells through necrosis-like cell death [8].

In the present work, it has been observed that CV, F1 and F2 fractions from B. globulifera increase the cytotoxic effect induced by cisplatin under specific conditions. The exposure to $\mathrm{F} 1$ at $10 \mu \mathrm{gmL}^{-1}$ induced a decrease of $40.02 \%$ in MTT reduction versus $11.12 \%$ by cisplatin. However, the pre-exposure to F1 $\left(10 \mu \mathrm{gmL}^{-1}\right)$ provoked a decrease in MTT reduction of $66.30 \%$ (Figure $4 \mathrm{~B})$. The combination of $\mathrm{F} 1\left(10 \mu \mathrm{gmL}^{-1}\right)$ and $25 \mu \mathrm{M}$ cisplatin decreased the MTT reduction to $67.57 \%$, which may indicate the absence of a difference between $10 \mu \mathrm{M}$ and $25 \mu \mathrm{M}$ cisplatin (Figure 4B). The

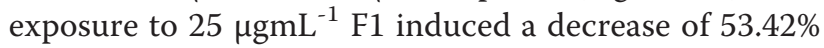
in MTT reduction but in combination with $25 \mu \mathrm{M}$ cisplatin, which by itself induced a decrease of $25.55 \%$ in MTT, there was a decrease of $72.55 \%$ (Figure 4B).

A similar effect was observed when lung adenocarcinoma cell line was exposed to $25 \mu \mathrm{gmL}^{-1} \mathrm{~F} 2$ followed by $10 \mu \mathrm{M}$ cisplatin, which induced a decrease of $51.56 \%$ in MTT reduction, while $25 \mu \mathrm{gmL}^{-1}$ F2 induced only a decrease of $33.48 \%$ and $10 \mu \mathrm{M}$ cisplatin a decrease of $11.12 \%$ in MTT reduction (Figure $4 \mathrm{C}$ ).

LDH activity was measured in a cell culture medium, since this enzyme is released under conditions of cell damage, wherein we observed that $10 \mu \mathrm{gmL}^{-1} \mathrm{CV}$ induced an increase of $17.5 \%$ of activity versus $98 \%$ by $25 \mu \mathrm{M}$ cisplatin; the combination induced $166.59 \%$ of increase (Figure $5 \mathrm{~A}$ ). The augmentation of LDH activity was $45 \%$ after exposure solely to $\mathrm{CV}$ at $25 \mu \mathrm{gmL}^{-1}$, but rose to $1423.3 \%$ when this $\mathrm{CV}$ was combined with $25 \mu \mathrm{M}$ cisplatin (Figure 5A). This finding may signify the absence of a real difference between 10 and $25 \mu \mathrm{gmL}^{-1}$ CV. Similarly, the $71.6 \%$ increase in LDH activity produced by treating cell culture with only F1 at $25 \mu \mathrm{gmL}^{-1}$ rose to $185.8 \%$ when the fraction was combined with $25 \mu \mathrm{M}$ cisplatin (Figure 5B).

Based on the results of the present work, we suggest not only that CV, F1 and F2 may present different mechanisms of cell damage in lung adenocarcinoma cells, but also that $\mathrm{CV}$ may augment cell damage by compromising the membrane, given the evident changes in LDH release (Figure 5A), and F2 fraction, which could cause higher mitochondrial damage, since MTT reduction is related to mitochondrial activity (Figure 5C). However, F1 fraction may produce greater mitochondrial alterations and membrane damage (Figures $4 \mathrm{~B}$ and $5 \mathrm{~B}$ ) than $\mathrm{CV}$ and F2 fraction.

Interestingly, this study proposes the usage of cisplatin at a dose below $\mathrm{IC}_{50}$, which in turn might represent fewer side effects. It is also interesting that cisplatin causes hardly any mitochondrial damage below $25 \mu \mathrm{M}$; however, the F1 and F2 fractions caused more damage, as measured by MTT reduction, than cisplatin alone while their combination seems to produce an additive effect (Figure $4 \mathrm{~B}$ and $\mathrm{C}$ ). It is also compelling that the combination of $\mathrm{CV}$ and $\mathrm{F} 1$ fraction with cisplatin appears to have synergistic effect, specifically in LDH release (Figure $5 \mathrm{~A}$ and $\mathrm{B}$ ).

Based on the data of the present work, we suggest that more studies are needed to investigate the cytotoxicity mechanism of CV, F1 and F2, which could help to design a combinatory treatment to increase the effects of antineoplasic agents, including cisplatin. We also suggest that these compounds may execute their toxicity though a different cellular mechanism that includes mitochondrial damage and alterations of the cell membrane.

\section{Conclusions}

We observed that CV of B. globulifera and its F1 and F2 fractions obtained by Sephadex G-50 M gel filtration have a cytotoxic effect on the A549 lung cancer cell line. The F1 fraction had the greatest effect compared with CV and F2. The combination of antineoplastic drugs and sea anemone toxins might allow a reduction of chemotherapeutic doses and thus mitigate side effects. It will be necessary to evaluate not only the damage and action mechanisms in lung adenocarcinoma cells, but also whether these compounds are cytotoxic to different types of lung cancer cells and other cancer cell lines, including breast, cervix and colon cancers, each of which has a high incidence and prevalence.

\section{Competing interests}

The authors declare that there are no conflicts of interest.

\section{Authors' contributions}

HIME performed experiments; YIC designed experiments and drafted the manuscript; IESM designed experiments and drafted the manuscript; JSR conceived, designed, coordinate the study and drafted the manuscript. All authors read and approved the final manuscript.

\section{Acknowledgments}

This study was supported by the grant from Dirección General de Asuntos del Personal Académico (DGAPA) of the Universidad Nacional Autónoma de México (UNAM), grant number IN 202309 and IB 201112 and CONACyT grant number 127656. We thank the CONACYT for scholarship to HIME 190209, Rebeca Candia Zulbarán, Sergio Guendolain, Fernando Negrete-Soto, Cecilia Barradas, and Laura Celis Gutiérrez for their help in field and laboratory work. Thank Fanny Bernal for her support with cell cultures. 


\section{Author details}

${ }^{1}$ Facultad de Ciencias Marinas, Universidad Autónoma de Baja California, Ensenada, Baja California State, Mexico. ${ }^{2}$ Unidad de Biomedicina, Facultad de Estudios Superiores Iztacala, Universidad Nacional Autónoma de México, Tlalnepantla, Estado de México, Mexico. ${ }^{3}$ Unidad Académica de Sistemas Arrecifales, Puerto Morelos, Instituto de Ciencias del Mar y Limnología, Universidad Nacional Autónoma de México, Puerto Morelos, Quintana Roo State, Mexico.

Received: 30 October 2012 Accepted: 5 December 2012

Published: 7 May 2013

\section{References}

1. Travis WD, Rambilla E, Müller-Hermeling K, Harris CC (Eds): World Health Organization classification of tumours. Pathology and genetics of tumours of the lung, pleura, thymus and heart. Lyon: IARC Press; 2004:344.

2. Shen H, Hu D, Du J, Wang X, Liu Y, Wang Y, Wei J, Ma D, Wang P, Li L: Paclitaxel-octreotide conjugates in tumor growth inhibition of A549 human non-small cell lung cancer xenografted into nude mice. Eur J Pharmacol 2008, 601(1-3):2329.

3. Panchal RG: Novel strategies to selectively kill cancer cells. Biochem Pharmacol 1998, 55(3):247-252.

4. Natarajan $N$, Thamaraiselvan $R$, Lingaiah $H$, Srinivasan $P$, Periyasamy BM: Effect of flavonone hesperidin on apoptosis of human mammary carcinoma cell line MCF-7. Biomed Prev Nutr 2011, 1(3):207-215.

5. Köberle B, Tomicic MT, Usanova S, Kaina B: Cisplatin resistance: preclinical findings and clinical implications. Biochim Biophys Acta 2010, 1806(2):172-182.

6. Pyo JS, Ju HK, Park JH, Kwon SW: Determination of volatile biomarkers for apoptosis and necrosis by solid-phase microextraction-gas chromatography/mass spectrometry: a pharmacometabolomic approach to cisplatin's cytotoxicity to human lung cancer cell lines. J Chromatogr B Analyt Technol Biomed Life Sci 2008, 876(2):170-174.

7. Miller RP, Tadagavadi RK, Ramesh G, Reeves WB: Mechanisms of cisplatin nephrotoxicity. Toxins 2010, 2(11):2490-2518.

8. Soletti RC, de Faria GP, Vernal J, Terenzi H, Anderluh G, Borges HL, MouraNeto V, Gabilan NH: Potentiation of anticancer-drug cytotoxicity by sea anemone pore-forming proteins in human glioblastoma cells. Anticancer Drugs 2008, 19(5):517-525.

9. Anderluh G, Macek P: Cytolytic peptide and protein toxins from sea anemones (Anthozoa: Actinaria). Toxicon 2002, 40(2):111-124.

10. Maček $P$, Zecchini M, Stanek K, Menestrina G: Effect of membranepartitioned $n$-alcohols and fatty acids on pore-forming activity of a sea anemone toxin. Eur Biophys J 1997, 25(3):155-162.

11. Tejuca M, Dalla Serra M, Potrich C, Álvarez C, Menestrina G: Sizing the radius of the pore formed in erythrocytes and lipid vesicles by the toxin Sticholysin I from the sea anemone Stichodactyla helianthus. J Membr Biol 2001, 183(2):125-135.

12. Tejuca M, Anderluh G, Dalla Serra M: Sea anemone cytolysins as toxic components fo immnunotoxins. Toxicon 2009, 54(8):1206-1214.

13. Pentón D, Pérez-Barzaga V, Díaz I, Reytor ML, Campos J, Fando R, Calvo L, Cilli EM, Morera V, Castellanos-Serra LR, Pazos F, Lanio ME, Álvarez C, Ponds T, Tejuca M: Validation of a mutant of the pore-forming toxin sticholysin-I for the construction of proteinase-activated immunotoxins. Protein Eng Des Sel 2011, 24(6):485-493.

14. Fedorov S, Dyshlovoy S, Monastyrnaya M, Shubina L, Leychenko E, Kozlovskaya E, Jin JO, Kwaj JY, Bode AM, Dong Z, Stonick V: The anticancer effects of actinoporin RTX-A from the sea anemone Heteractis crispa (=Radianthus macrodactylus). Toxicon 2010, 55:811-817.

15. Milla L, Sánchez-Rodríguez J, Segura-Puertas L: Dermatitis por contacto con Bunodeopsis globulifera (Cnidaria anthozoa). Dermatología Rev Mex 2003, 47:140-141.

16. Mosmann T: Rapid colorimetric assay for cellular growth and survival: application to proliferation and cytotoxicity assays. J Immunol Methods 1983, 65(1-2):55-63.

17. Bradford MM: A rapid and sensitive method for the quantitation of microgram quantities of protein utilizing the principle of protein dyebinding. Anal Biochem 1976, 72:248-254.

18. Laemmli UK: Cleavage of structural proteins during the assembly of the head of bacteriophage T4. Nature 1970, 227(5259):680-685.
19. Ravindran VS, Kannan L, Venkateshvaran K: Biological activity of sea anemone proteins: II. Cytolysis and cell line toxicity. Indian J Exp Biol 2010, 48(12):1233-1236.

20. Batista U, Macek P, Sedmak B: The cytotoxic and cytolytic activity of Equinatoxin II from the sea anemone Actinia equina. Cell Biol Int Rep 1990, 14(11):1013-1024.

doi:10.1186/1678-9199-19-12

Cite this article as: Monroy-Estrada et al:: Toxins from the Caribbean sea anemone Bunodeopsis globulifera increase cisplatin-induced cytotoxicity of lung adenocarcinoma cells. Journal of Venomous Animals and Toxins including Tropical Diseases 2013 19:12.

\section{Submit your next manuscript to BioMed Central and take full advantage of:}

- Convenient online submission

- Thorough peer review

- No space constraints or color figure charges

- Immediate publication on acceptance

- Inclusion in PubMed, CAS, Scopus and Google Scholar

- Research which is freely available for redistribution 